
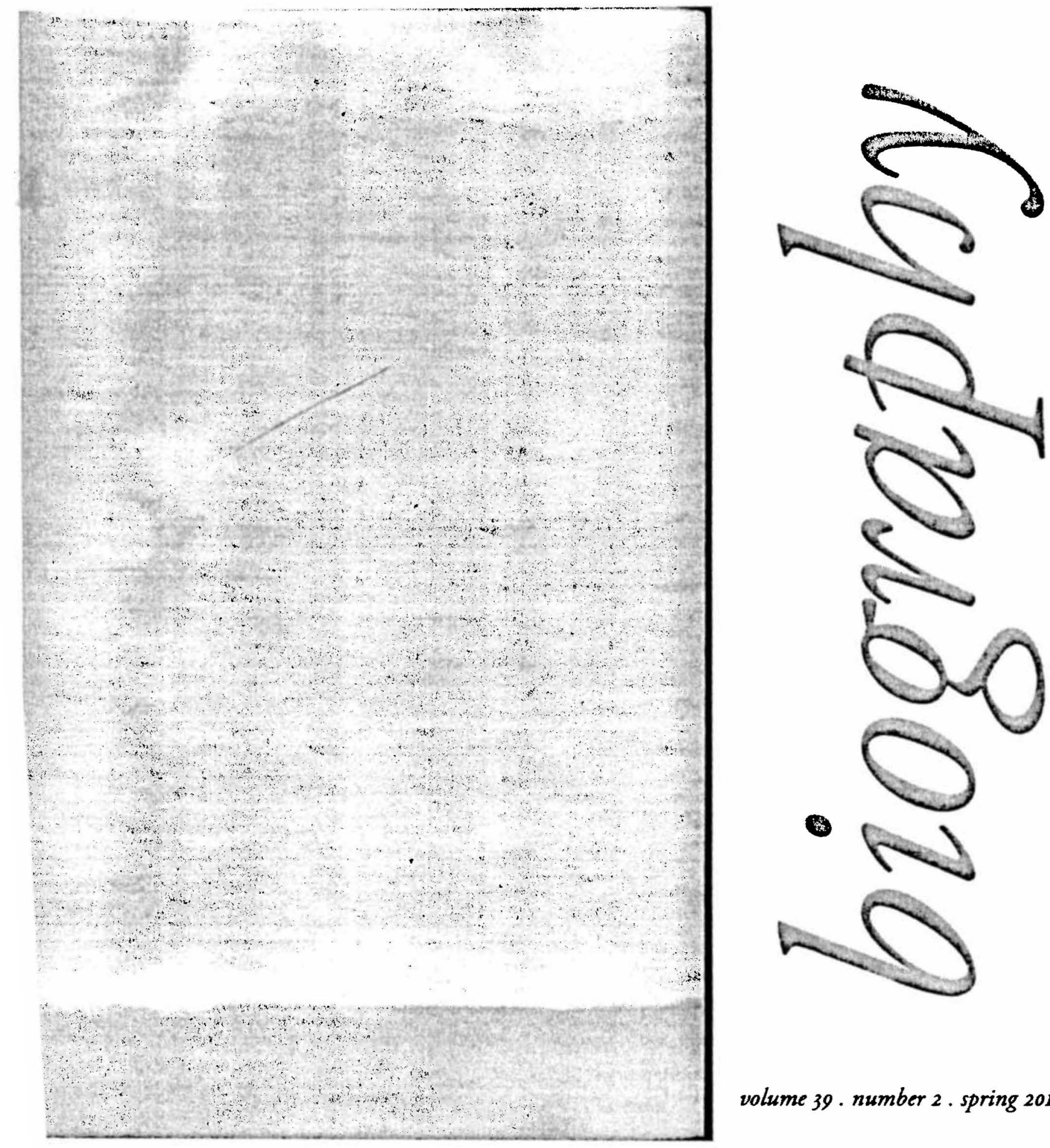

an interdisciplinary quarterly
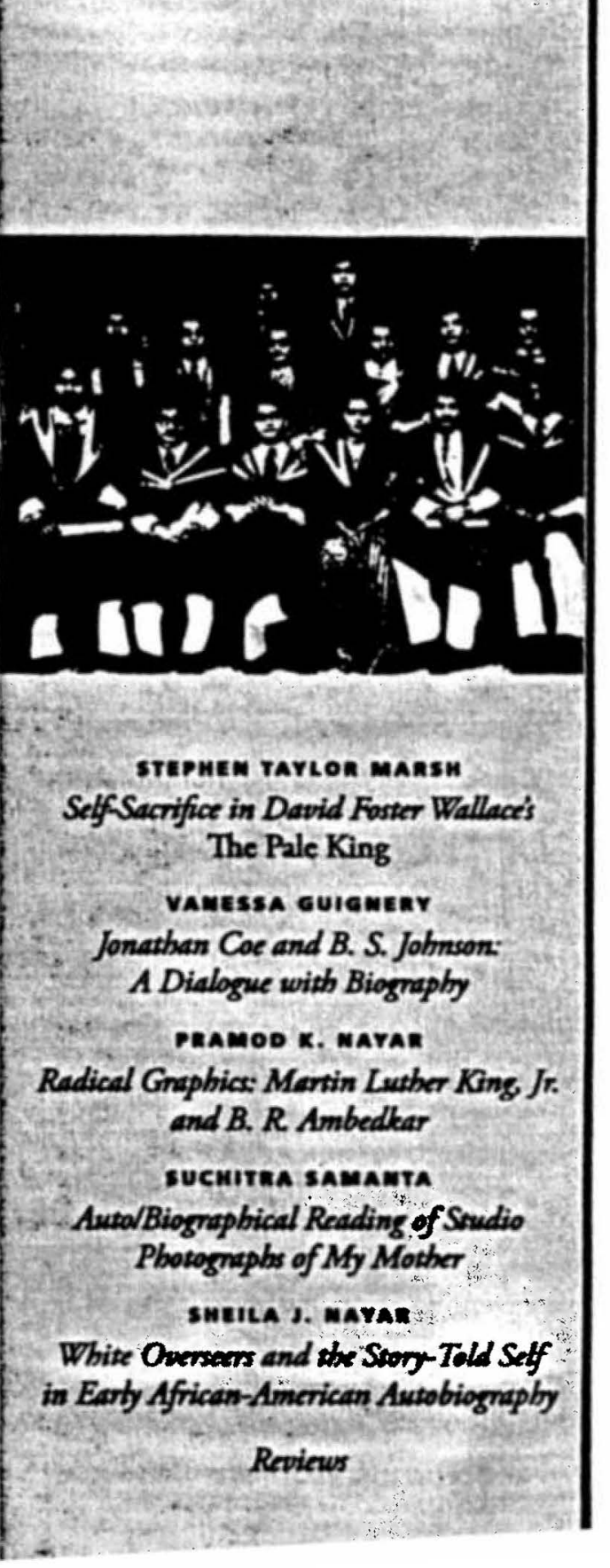

volume 39 . number 2 . spring 2016 


\section{AN INTERPRETIVE AUTO/BIOGRAPHICAL READING OF STUDIO-POSED PHOTOGRAPHS: TELLING MY MOTHER'S LIFE IN COLONIAL AND POST-COLONIAL INDIA}

\author{
SUCHITRA SAMANTA
}

\section{INTRODUCTION}

In this essay, I "tell" my mother's life through photographs of her, specifically those raken in studios, ${ }^{1}$ but as more than a chronological life story. I intend to rediscover the person that she was, or was not, but chose to present. A deeply personal as well as feminist sensibility inspires this essay, to give voice and substance to a long silence. As colonial India approached independence, $\mathrm{Ma}$ successfully availed of opportunities for women to study medicine. But she would confront, in her circumstances and in her time, obstacles to her aspirations, and she died in her mid-forties. I draw from historical research on photography and on British initiatives to train Indian women in medicine, as well as other "texts," to offer context and dimension to my reading of the photographs. I conclude with orher possible narratives (cultural, religious, and philosophical) that contribute to my endeavors, a half century after her death.

Surabala (née) Karmakar (1918?-1965) came from a middle class (bhadralok) family of modest means in Bogra, in then East Bengal and present-day Bangladesh, in British India. She studied medicine at Calcutta Medical College (CMC), entering a class of ninety-seven men and eight women in 1935 , and graduaring with several high awards in 1941. She worked at various hospirals in and near Calcutra ${ }^{2}$ from 1942 on, and married my father, her classmate Sushil Kumar Bardhan Ray ("Baba, 1918?-2009) in 1946. Illness during her late pregnancy with me at the end of 1948 forced her to give up work. For reasons centrally related to the partition of India and Pakistan (1947), such as the loss of my paternal grandparents' home and farmland in then East Bengal, and my father's need for secure work with the (British) Indian Medical Service (IMS) that would support both his own large family as well as Ma's financially struggling family, she would not again have a career. She accompanied my father as he continued to serve in independent India's Army Medical Corps, in his postings across India. As I turned sixteen, Ma died of a stroke in Pune, western India.

I have gathered these facts from various sources, including my father's unpublished memoir (in English), family recollections, my own memories, testimonials written by Ma's seniors at work, and CMC Annual Reports and certificates. But these are others' voices that speak to Ma's life's trajectory and personality. In this essay, I seek some semblanice of her voice in professionallytaken photographs, ones she chose to take, even though those other voices, including mine, through questions, interpretation, and comment, necessarily intervene. Three of the photographs are from family collections. Five are from an album evidently compiled by $\mathrm{Ma}$ as she graduated, dated in her handwriting "5th February 1942 " on the inside front cover.

Different aspects of a "self" are revealed in these photographs, from a spirited young medical student, to a newhy minted professional, to a new wife's gift of her photograph to her husband. However, one photograph of her as a mother with her young children (my sister and me) suggests a domesticity I do not associate with Ma. Anecdotal recollections by family and descriptions of her or observations from Baba's memoir support that reading of a woman who is likable and modest even as she is unconventional, and a brilliant high-achiever. But there is, I argue, a coherence between the younger woman and the mother I remember, who was not particularly sentimental, was given to rages, and ambitious to educate her daughters, but who could be deeply caring. I proceed, however, with some caution in my endeavor, given the uncertainties at stake.

The theme of ambiguity in reading photographs, from a point discant in time and possibly space, is taken up by several scholars. Conventions of photography at an earlier point in time, for example, contribute to particular kinds of posed images. A studio picture may have been dictated by the photographer, implying an element of playacting and a subject who may or may not have chosen to represent herself in that way (Karlekar, Re-visioning 11). Commenting on the "inauthenticity" and even "imposture" of the posed photograph, Barthes observes that "I constitute myself in the process of "posing" (10), and that as subject, he is at the same time "the one I think I am, the one I want others to think I am, the one the photographer thinks I am, and the one he makes use of to exhibit his art" (13).

A significant aspect for the viewer especially of family photographs is the emotion that colors that seeing. Even as different people might see an old 
photograph in different ways, and offer different interpretations and even contexts, the familial seeing can uphold or contest dominant family ideologies, history, and structure (M. Hirsch, Family 117). While the subject aspires to her "visual immortality," the viewers "answer to their own longings and curiosities" (J. Hirsch 9), navigating berween "ambiguity, intention and actuality" (12). For viewers, such pictures are both "text and image, intricately tangled in a narrative web" connecting family in emotions of "desire and disappointment, love and loss," revealing even as they conceal (M. Hirsch, Family 4-5).

Other writers suggest that if a reader's affect and a photographer's control over the image contribute to what is unknowable in a photograph, social, cultural, and historical contexts can inform the viewer. Bourdieu describes phorography as a "system of schemes of perception, thought and appreciation common to a whole group" (6), noting that photographic conventions are associated with the values and ethos of a class (8). Analogously, Barthes proposes the concept of studium: the political, social, and historical context of a photograph for the viewer (28). He also, interestingly and with pertinence to some of the photographs I will discuss, distinguishes studium from punctum, by which the viewer is "punctured" by some element in the photograph, forcing an engagement. The punctum is there without the intention of the photographer, startling the viewer (47) and "disturbing the studium" (27). If the studium explains, the punctum inspires curiosity, questions, and possibly affect, critique, and a personal investment (see also M. Hirsch, Family 4; Karlekar, Re-visioning 10). Citing Barthes (76), Christopher Pinney examines the "event" of the photograph at the moment of exposure, distinguishing the "corps" from the "corpus" - that is, the relationship of that event to the psychic, social, and historical reality within which it is embedded-and asks if what the camera records can then be called "true" ("Coming Out Better" 25).

In light of the preceding, to what degree of veracity can I aspire in writing Ma's life, surmising at the person she was this many years later? Looking at my mother's photographs invokes in me a sense of poignant loss and hurt for a life of promise cut short. Such "looking" has impelled questions about my own life, its gendered trajectory, and travails. It is a feminist gaze I bring to bear, one that includes an old grief and many questions, for I have come to a point of emparhy that connects Ma's life narrative with my own. But I proceed with caution, wary of a "wanting to see."

\section{THE PAST AS PROLOGUE}

I begin with a particular photograph I had seen over the years only in passing on the wall at my sister's home in India, but which I actually noticed only in 2013 (Figure 1).

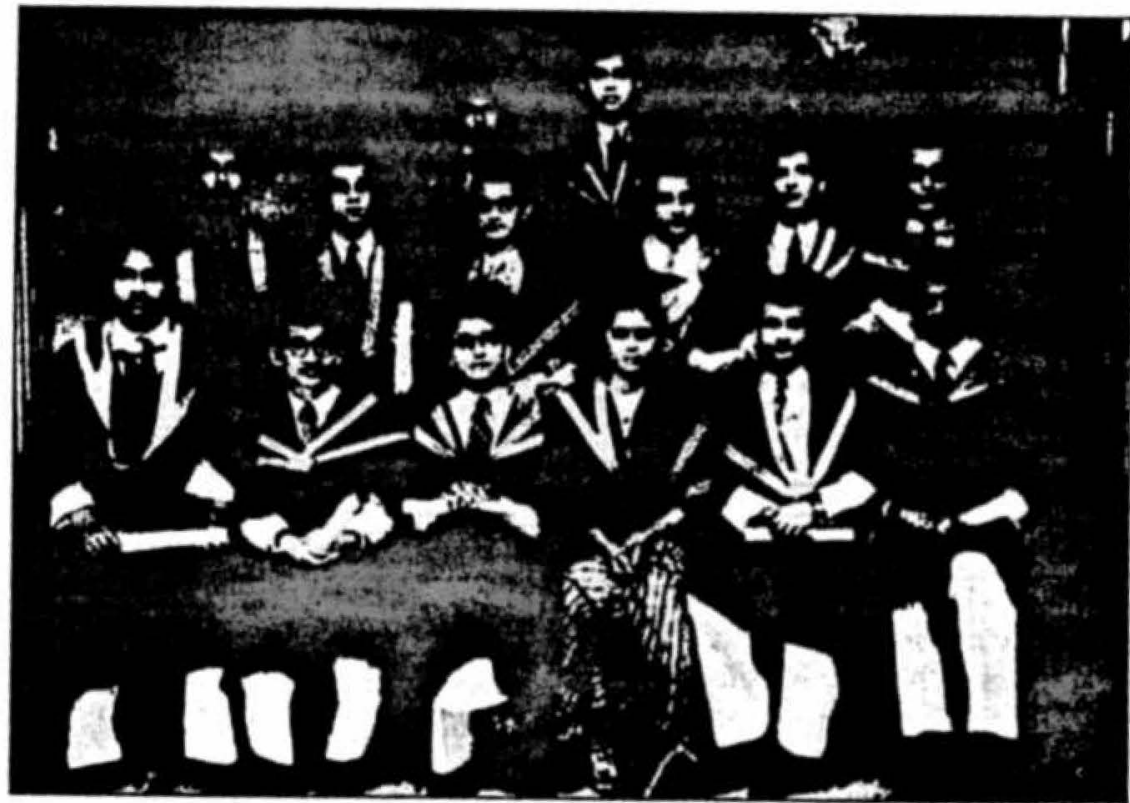

Figure 1. CMC group graduation photo, 1941 (photo courtesy of the author).

$\mathrm{Ma}$ is the only woman among thirteen men in a professionally-taken group graduation photograph. The picture has no provenance, but my family and I have surmised it to be of her graduation from CMC in 1941, given the gender ratio (and that her secondary education was at an all-girls school). She sits with her left leg sticking out slightly, the sole of her shoe to the camera, in a culture where such a posture can be seen as disrespectful. Unlike the others, she holds no diploma, while her robes, open where the men's robes are closed, slide slightly off her left shoulder. She appears impatient, spirited, as she looks at the camera.

Was she late in showing up for this photograph, and had she left her diploma behind? Was she confident about her place as the sole woman in the group, or defiant, or both? Five of eight women in her entering class would graduate (Annual Report). Did the photographer insert the other four in other group photographs? Does $\mathrm{Ma}$ appear confident because she has successfully concluded a difficult, expensive, six-year course at a prestigious medical institution, in spite of her financially struggling family? Is she confident too because she is evidently beautiful? What, I ask, lies behind such achievement for a woman in her day, and such attitude? 
li) discover the narrative of her lite, I connect a particular memory, an image associnted with Mas final dass, and one immediately after her death, to the phorograph in Figure 1.1 remember $\mathrm{Ma}$ at the end, pale, thin, silent, and utterly vulnerible as she sits on the verandah of our home in Pune, watching - me leave for the tennis cours after school. It is an image that sharply contrasts with Figure 1. She would have rwo mild strokes in 1964, and her lase one in February 1965, and she died on April 11th, 1965. The day after her cremarion on a wood pyre, my farher and I sifted through her ashes (to cast into the river Hooghly at her funeral later in (alcuta). I found a small, thick, charred piece of bone. Even as my young mind asked how this was all that could be left of the lively, lovely, fierce mother I had known, I showed the bone to Baba. He said quierly, "That's the bone from her forehead. It does not burn easily:" I reflected even then that my heretofore assured and unquestioned childhood could never again be so.

A day or so after Ma was cremared, I saw Baba weeping quietly as he sat alone on the verandah where $M a$ used to sit. He would raise two young daughters by himself in conservative Indian sociery, a formidable task. Howcere ficing social criricism of a growing and now morherless daughter, my farher sent me to a reputable liberal arts institution, Lady Brabourne College in (alcutta ro study English literature. In my second year of college, at age seventecn. Baba (and my extended timily) began to pressure me into marriage. fearing I might bring dishonor to the family-despite my own excellent ardemic achicuments at the time. I married at age twenty, by choice of a kind, purting my own drcams behind me. I left that marriage twelve vars later with the clear sense that I deserved beter and could do more than "rradition" demanded, and further, that much had gone wrong in Mas life, not necessarily by choice. Determined thar I would ery to do what she could not. I applied ro and was admitted to graduate school at the University of Virginia in the Linited Srates. I came to the USA on a wing and a prayer, to conrinue my incerrupted studies and start over. Baba, though disapproving of my decision, paid for a semester's ruitjon and my air ticket-what he could atford.

A halt-century after her death, the mother of a daughter myself, an academic, and a teminist. I reftect on the many contingent choices and compromises 1 bawe had to make in my lite and in my own aspirations to higher education. for no reason other than that I was born a girl. Today, I reflect on the irony of what my tather sad afier Ma was cremated. Behind that remnant of bone rhere had been a mind, the intense inrelligence of a woman who had dreamed in her day of whar she could be, and had availed of new opportunities for women in British India. She had dared.

\section{THE MOTHER I REMEMBER}

There is one surviving studio photograph of $\mathrm{Ma}$ wirh my vounger sister and me. I estimate its date as around 1954, based on how old we appear to be (Figure 2). I will start with what surprises me about it, and why. In the subsequent section I will return to photographs in Ma's album, with the intent of connecting the ambitious medical student, the doctor, and the mother I rementer.

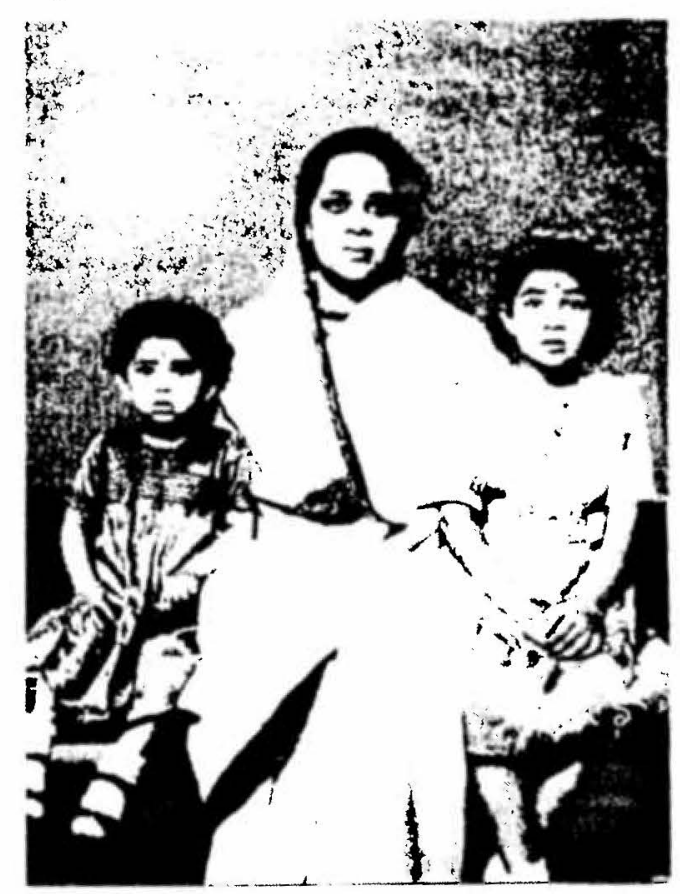

Figure 2. Ma, with my sister and $m$ (photo courtesy of the author)

This is not the mother I remember. Her head is covered with the and anl (end) of her sari, a traditional method of veiling ( $g$ homta) for married Hindu women at their wedding, but especially in the presence of in-laws. Ma did nor like doing this, my father would say, nor do I remember her doing so. Here, she appears to be the image of compliant, conventional domesriciry, a Bengali wife and mother, comfortably plump, with her young daughers, in a pose of maternal protection and love. Did she choose such a pose, or did the phorographer choose for her? Did he ask her to cover her head:

Ma was not, as I remember, concerned with marters domesric or religious. No altar to Hindu deities graced our home. Nor was she overty sentimenta! 
or expressive in her love for her children, though this may be more of a cultural convention, or the lack of mothering in her own life. ${ }^{3}$ However, in retrospect, I realize that Ma's concern and care for us was expressed in her uncompromising, even punishing, expectations for her girls' academic performance. My sister and I were sent to excellent and expensive schools in the cities where my father would be posted, where Christian, mostly European nuns taught us in English. This could not have been easy to afford for my young parents, given their financial commitments to both sides of the family. In post-colonial India, however, such an education afforded the best opportunities, as well as social status, and we were, I reflect today, being given every advantage.

I feared Ma's fierce wrath, the colorful curses she directed at her daughters, in Bengali "You sister-fucking child" was one gender-inappropriate one I recall). With dispatch, she severed the tail of our spaniel puppy with a razor blade, declaring "It's only cartilage," and she would know. Since I.witnessed this at a tender age I could claim a lifetime's trauma, but I also recall an unfazed puppy. I held a deep grudge towards her for her unsentimental attitude to my beloved dogs- - "disappearing" (as in unilaterally abandoning) one when it gave birth to a litter of puppies. In another context I, then around nine, warched in awe as she roundly beat (by hand) her much younger halfsister into taking a nursing examination, when the latter balked. Ma had no inheritance, two feckless brothers, a father long dead, and was without an income to support her family, including an illiterate stepmother. After the beating, my aunt would take the exam, and work in a reputable cancer hospital in Calcutta, even rising to a senior position towards the end of her career.

But I also recall moments of maternal tenderness. When I was about eight years old, she would diagnose me when I developed acute appendicitis, and weep all the way in the ambulance that took me to the hospital. Since she was not usually given to emotion, I remember, even at the time, being surprised. After I severely pulled a muscle at a high school athletics meet (bringing home the Senior Division track and field championship), Ma stayed up through the night massaging my back with garlic boiled in hot mustard oil - but grounded me from all sports indefinitely, an injustice I chafed at but abided by, out of fear. I realize now that she gave short shrift to my love of, and success at, sports for fear that an injury might jeopardize the future she had in mind for me. Education, she believed, would empower her girls, where marriage would disempower them. Hence her repeated declaration to family that she would never marry us off, but educate us to the farthest extent possible. Yet, she allowed me to roam freely with my young friends through the fields and woods that surrounded the old British bungalows in which we lived-spaces with aggressive monkeys, and poisonous snakes - a freedom I reveled in, and evidently survived.
During these years $\mathrm{Ma}$ "speaks" herself once, in the only surviving piece of writing by her. On a yellow postcard, dated March 12, 1963 and handwritten in ink, in Bengali, Ma writes to my farher as (I assume) he sees to family affairs in Calcutta. My translation follows:

Dear Bardhan,

I just had my abcess [sic] opened. I got this done by Colonel B-, [and] M-. My blood sugar is not high. At noon today I had the operttion, and returned home by 2 pm. B-- [another doctor] organized everything. Injection of pethidine and local spray was used for the procedure. There is nothing to worry about. The dressing will be changed daily. It will take about a week to clear up. And the children are well. For two to three days I suffered from the pain. I hope that it will be better by romorrow Don't be worried, everyone is looking after me well. Take your time to do what you need to before you return. The children are all right. Ma ther stepmother, then staying with us] is suffering from lumbago, as you know.

$I$ end here,

Bochan

The tone of the postcard is gentle, caring, and in control even as it expresses her pain. It also hints at her stoical, courageous forbearance. She is the doctor, in her details of the surgical procedure she has just undergone at the army hospital, and the names of the anesthetic substances used (in English). But she is also wife, mother, and daughter, with different responsibilities. She addresses Baba by his last name, as he was known in college (and contrary to the traditional usage where a married woman, even today, often does not address her husband by his first name). He would call her "Snub Nose," Bochan, which is how she signs off.

In sum, even if colored in these brief vignettes by a child's, then a rebellious teen's (possibly biased) memory of a demanding mother, Ma seems to have been her own person-contrary to her placid self-presentation in the photograph-in control, defining maternal love unsentimentally, holding me to high educational achievement, and setting boundaries even as she allowed me freedom.

\section{THE MEDICAL, STUDENT AND DOCTOR}

The contents of Ma's album, based on the few pictures with dates, span her college years from 1936, to photographs at their wedding, and subsequently, at least till 1946. Besides the three professionally taken photographs I will discuss, the other photographs in the album are ones she chose to include. For example, there are studio photographs of several women friends, non-studio ones of my father (traveling with the IMS), the young doctor herself at what 
appear to be places of work, the new bride with her husband at the wedding venue in Calcutta, and my twin paternal uncles. ${ }^{4}$

Scholarship on the centrality of the studio-taken photograph for the upwardly mobile Indian middle classes (and aspiring women) in colonial India, as well as British initiatives to educate Indian women in medicine, provides some context to my discussion. Karlekar notes that by the mid-nineteenth century particular poses and backdrops in studio photography had spread from Europe to the colonized territories (Re-visioning 3; Visual xii). ${ }^{5}$ Ramaswamy adds that in the visual regimes of Europe and its colonies, "image-making technologies" such as photography and film were "imperially dispersed but locally appropriated in creative and unexpected ways" (2). Pinney notes the "mechanization and industrialization of perception" in this technological innovation, but also criticizes photography as having "too many meanings for any efficacious nationalist instruction" (Coming 49). He also notes, however, the "central" place of the studio in people's encounters with photography in early twentieth century India, where customers go to "local studio impresarios" in the hope that they will "come out better" in the hands of technicians who use costume, background, lighting, and camera angles to produce the "desired look ... or expression" ("Coming Out" 29-30). In this vein, Geraldine H. Forbes, also noting how photography found a market with both colonial authorities and the new Indian professional class ("Small Acts" 59), proceeds to "tell" the photographs of three women (supplemented substantially by interviews, references to memoirs, and personal letters), where meanings are not fixed but rather "objects of negotiation" between subject (the woman) and viewer. In these "showing photographs" the young women posed for prospective in-laws, but were, in fact, resisting both their own families as well as the in-laws (60). These "new women" of the 1920 s and 30s, wanting to pursue an education, resisted patriarchal authority by deliberately posing with body language or facial expressions not meant to please. Their photographs take on layered meanings, and argue against, says Forbes, the passive Indian woman (77).

The state of Bengal brought in 44 percent of the total revenue for the British, and their first capital, Calcutta, grew, as did the numbers of those Benzalis aspiring to white collar work as professionals. Women's emergent roles went together with such aspirations to mobility (Karlekar, Re-visioning 6). The photograph became "precious evidence" of such recently acquired mobilty and status, ourweighing the "proscriptions of caste and community" (72). For enterprising men and women, "the appropriate photograph" provided a sossible advantage for entering a new life (12).

In tandem with the changes I have described, a concern with educating ndian women came to the forefront from the mid-nineteenth century to the years approaching Independence. The "woman question," focused on alleviating Indian women's "degraded" condition through education, was seen as central to the definition of modernity for the new nation-to-be (Bala; Chatterjee; Forbes, "Medical Careers," Women; Ray; Seth 274). English-educated Indian women would bridge the gap berween tradition (as defined) and modernity - that is, they would be cognizant of their domestic responsibilities, and serve as a home's spiritual center, while men would do the public work and serve as a home's spiritual center, while men would do the public work woman" in an aspirant and modernizing India, was carefully defined and bounded, a "new patriarchy" that "legitimately" subordinated women (Chatterjee 248). The twentieth century women's movement, "inextricably bound" to the freedom movement, would question the private-public dichotomy (Ray 177). In fact, Bengali women would be reported in British newspapers as the "most dangerous" of revolutionaries (189).

Women, and their relegation to the domestic sphere, played a complex role leading to a need for women doctors in colonial India. The "elusiveness" of Indian women challenged the hegemonic ambitions of Western medicine (Arnold 4), especially in the space known as the zenana, the secluded inner quarters where wives and family members of affluent Indians resided. The zenana was an "uncolonized" space, a "battlefield" where diseases such as tuberculosis, as well as neonatal tetanus and infant mortality, ran rampant. The Western concepr of hospital births ran counter to notions of birth pollution and seclusion for women of the elite Hindu castes and Muslim women in purdah (256-57). ${ }^{7}$ As late as the First World War, urban middle class Indian women were reluctant to enter hospitals (258). While missionary women attempted through education to "penetrate the zenana" (256), scholarships were provided to train midwives (dai) in modern sanitation and medical knowledge, but with little impact even into the 1920s. Addressing public health issues associated with the women of affluent Indians was also an issue of strategic importance for the British, who sought both donations as well as support from them (Forbes, Women 60).

In response to the need to address women's health, the Lady Dufferin Fund, set up in 1885 and funded by the state as well as by private donations, was designed to be a separate medical system employing women doctors (as well as nurses, midwives, and hospital assistants) to serve in women-only zenana hospitals. The Fund had "considerable impact" on women's health and medical education, and the numbers of women and children attending hospitals in the first years after it was set up "represented a significant widening of the bounds of Western medicine" through the end of the nineteenth ing of the bounds of . The Fund initially recruited Western women to serve 
in India, who saw it as a career move, but many suffered health problems. They were criticized by Indian newspapers as ignorant of native traditions of childbearing, and returned home, at which point it was seen to be necessary to train Indian women. By 1928 the Fund had four hundred women doctors across India (268). Appointment to a Dufferin hospital was seen as prestigious.

"Widespread antagonism" confronted the first Indian women doctors. Kadambini Basu, who attended CMC on a scholarship and graduated in 1888, was appointed to the Lady Dufferin Women's Hospital. A good doctor and the mother of five children, Basu, however, was called a "whore" by a conservative Bengali magazine (Forbes, Women 162). Haimabati Sen (18661933) established a good practice at the Dufferin Hospital in Chinsurah. But she was treated as a midwife, and her title continued to be that of "hospital ussistant" (Forbes, "Medical Career" 520). Forbes quotes from Sen's memoir, where she describes her many domestic duties to her husband and children, interspersed with her work (Women 157).

In the early decades of the twentieth century, Indian middle class women, who saw Western medicine as modern and scientific, demanded more female medical professionals; they were also required for women working in the manufacturing sectors, for whom services were mandated by law (164). After World War I, in response to a greater need for women doctors, more medical institurions began to accept women. However, women living together in hostels faced the risk of breaking caste rules (see also Arnold 267). If they lived in private homes, they risked taunts traveling to classes. Professors separated female students from the men, and hence many women failed to graduate. Society had little tolerance for single working women, who also faced sexuII harassment. European and (Christian) Anglo-Indian women dominated he profession, earning much more than other women (Forbes, Women 166), sven though overall, women doctors of any race who worked in the Dufferin cospitals made one third the salaries of both British and Indian male doctors erving in the IMS.

Both in its official introduction of English, as the language of instruction $\mathrm{n}$ the arts and science in government-financed schools, and the establishment if the CMC, 1835 marks a seminal year. The CMC was founded on Euroean models, with instruction in English (Gorman 280). Its faculty was drawn rom the IMS, and its students from the Hindu upper castes (281-82; see also 3ala 112). ${ }^{8}$ Berween the years 1835 and 1858 the CMC was regarded as being in par with the best medical schools in Europe (Gorman 297). Between 1917 ind 1921 the numbers of students attending CMC rose (Bala 121), and after World War I, as government subsidies were withdrawn, affluent students paid tigh fees to attend (140).
I have no anecdotal or other evidence that $\mathrm{Ma}$ was aware of these new winds blowing across the nation as she entered high school, then college, and subsequently the CMC. The oldest of four siblings, she rode, with evident mbition and drive, a wave of opportunity for women in her day, while it is amestionable if her siblings made it past high school. In $1935 \mathrm{Ma}$ would enter mest prestigious medical college in eastern India (Gorman), $\mathrm{CMC}$, then the most prestigious medical college in her initial facility in Engwhere instruction was in English only. She acquired her initial faciliy in Eng lish at Vidyamoyee Girs Ma completed a two year Intermediate to CMC and also a program that relege, Calcutta, a requisite for entrance to a paternal uncle, she spoke the lanquired fluency in English. According to a paternal une CMC on a (Dufferin?) guage with greater fluency than Baba. She artended some part of this meager scholarship. I would learn from family that she sent some par make ends meet. money home to her struggling family, and offered tuitions to la (Figure 3)

An intriguing image appears on the first page of Oval in shape, an inch and half in size, it is centered on the black page. A cut-out, it may or may not be studio-taken but appears the album, evidendly notice not only because it appears right at the start of the album, claiming the album as hers, but for what it seems to reveal about Ma.

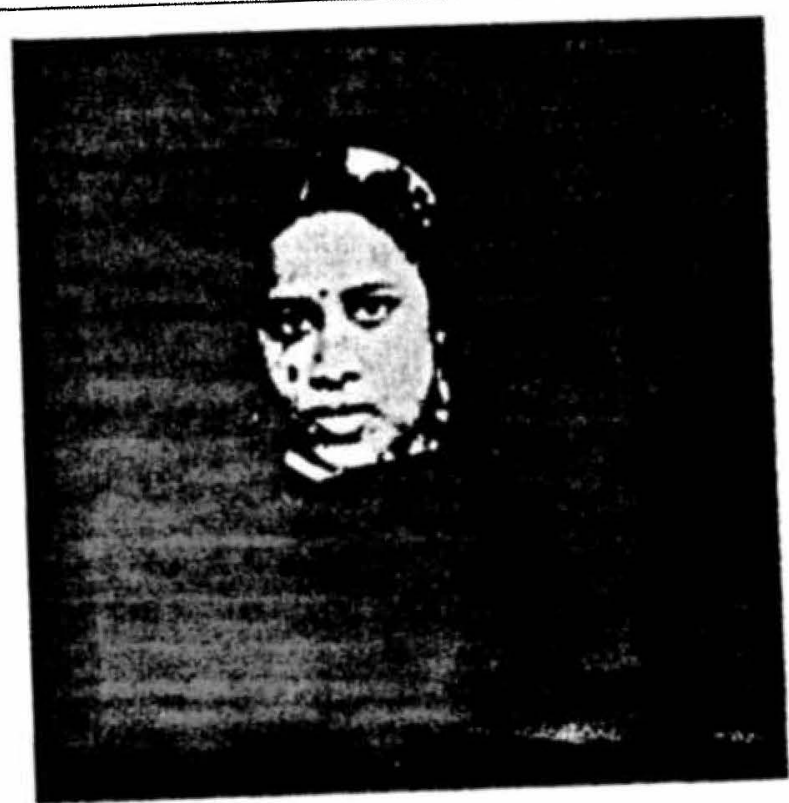

Figure 3. First page of Ma's album (photo courtesy of the author). 
Other than the disembodied presentation, the long, dangling earrings caught my eye, the picture's punctum, if you will. Did she borrow these from - a friend? What was the occasion of this picture? She does not wear such ostentarious jewelry in any other photograph, nor do I remember her wearing such flamboyant jewelry. Did she select this picture because it portrays a remarkably lovely woman-and one apparently aware of it? And why does she glue it, a face looking brightly, luminously, out from the black page at the start of her album? Why did she nor include the rest of herself? Were there others in this picture, people she cut out to present just herself?

This is followed by another photograph (Figure 4), this time of Ma looking our berween "Anima" and "Lila" (who are identified on the backs of lookrate, individual studio photographs of them in the album).

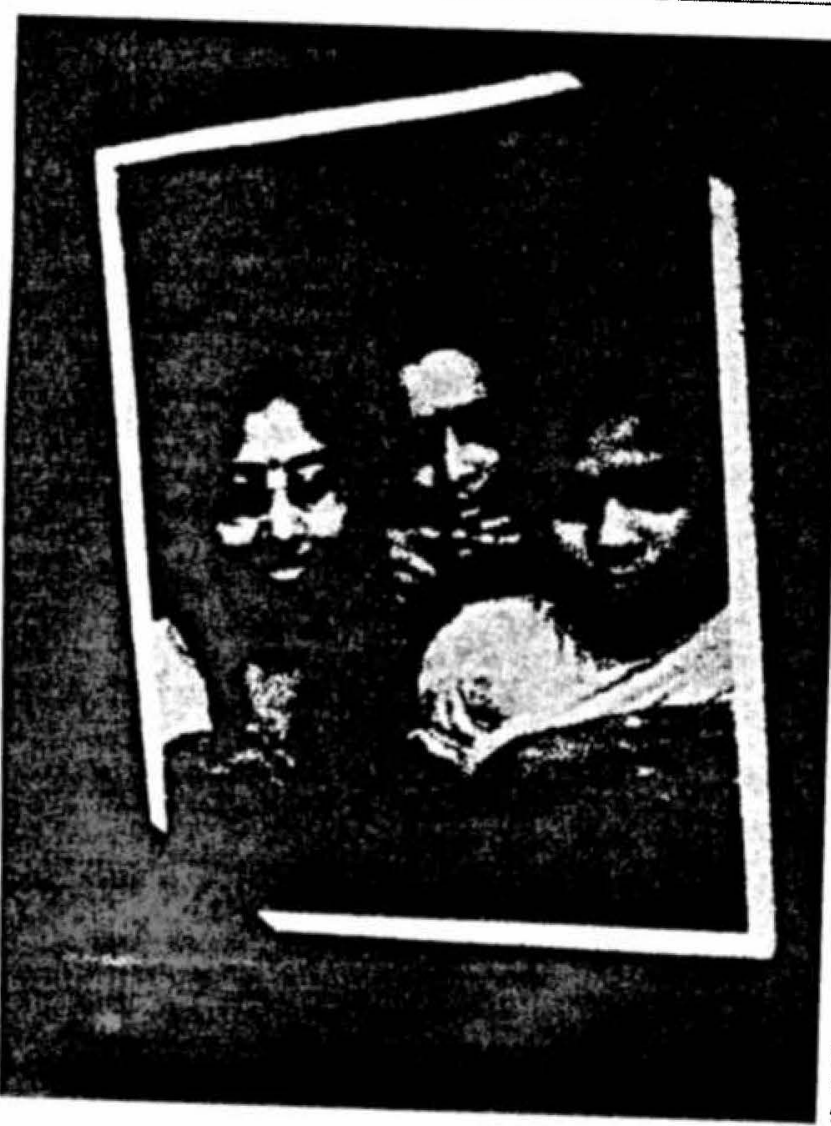

Figure 4. Ma, with her friends (photo courtey of the author)
This photograph shows what appears to be a conventional pose dictated by the studio photographer; all but one of her women friends appear in a similar pose, pictured from the bust up, with forearms and hands gracefully crossed in front, and visible on a table, or laced under the chin. ${ }^{10} \mathrm{Ma}$, with her two girlfriends, looks lively, even playful, while to her left Anima looks serious, and Lila has a little smile on her face. Given that the women in other studio photographs in the album at best hint at a smile, and mostly offer a three-quarters profile, Lila's smile is striking, as is the girls' direct gaze at the photographer. They look like they are having fun, a moment they want on record. As friends graduated and went their separate ways, they evidently "gifted" their studio photographs to $\mathrm{Ma}$ - there are other such "gifts" of women friends in the album, inscribed on the back, for example, "To S. Karmakar. From Lila."

In a photograph dated "5th Year, 1939" on its back, Ma presents a different image (Figure 5). Taken past mid-point in her studies at CMC, in this photograph Ma looks almost film-star-like in her pose, as, unsmiling, she looks off to her left, up, and into the far distance, with her arms crossed in front of her. Her long black braid hangs in front of her, over her right shoulder. She wears no make-up, as in all the other pictures, just a bindi, a black dor, in the center of her forehead. In none of the more informal pictures of her in the album does she wear a bindi. Evidently she has "dressed up" for

igure 5. Ma, 5th year, 1939 (photo courtesy of the author).

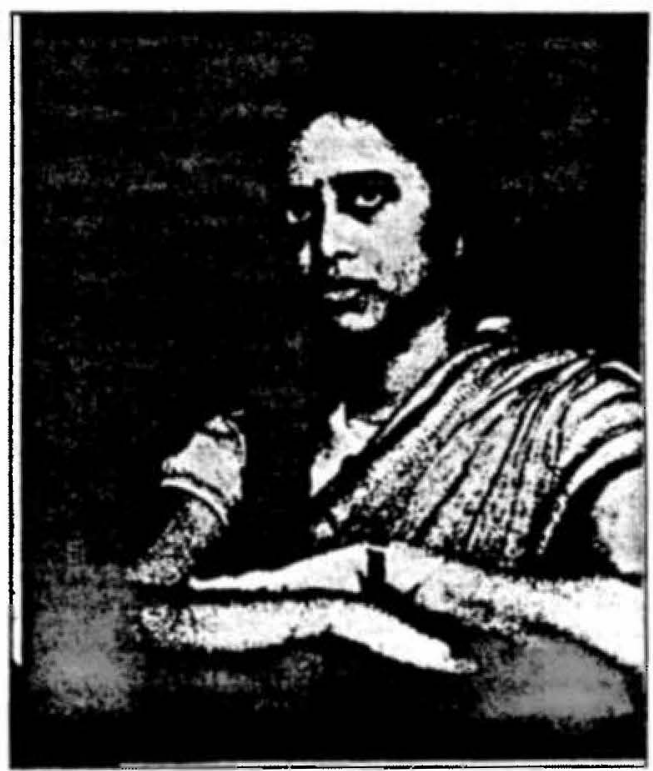



Ir studio pictures-all except, interestingly, the two graduation photographs
igures 1 and 6 ).

The album includes a second studio-taken graduation photograph of $\mathrm{Ma}$ one, though no provenance is provided (Figure 6). In this picture she stands cap and gown, clasping her rolled up diploma horizontally in front of her, both hands, one from above, the other from below. She leans a litcle to her $\mathrm{ft}$, a gentle, steady expression on her face. It contrasts, in its greater formaly, with how she appears in the group picture (Figure 1), as well as with Fig- 5, where she does not look directly at the camera.

A third studio photograph follows, dated 5th August, 1941, the year Ma aduated (Figure 7). This reveals a less glamorous, apparently more profesonal image of Ma. She wears no jewelry, a black bindi graces her forehead, , her right, at some distan braided, but at the back. She looks slightly away, her sight, at some distant point-but not into the far distance, as we see in gure 5. Like the other studio photographs of women in the album, her arms e crossed elegandly in front of her, on a table, but with a finger crooked. oks serious, and capable. Her lips are together, almost firm, less relaxed than

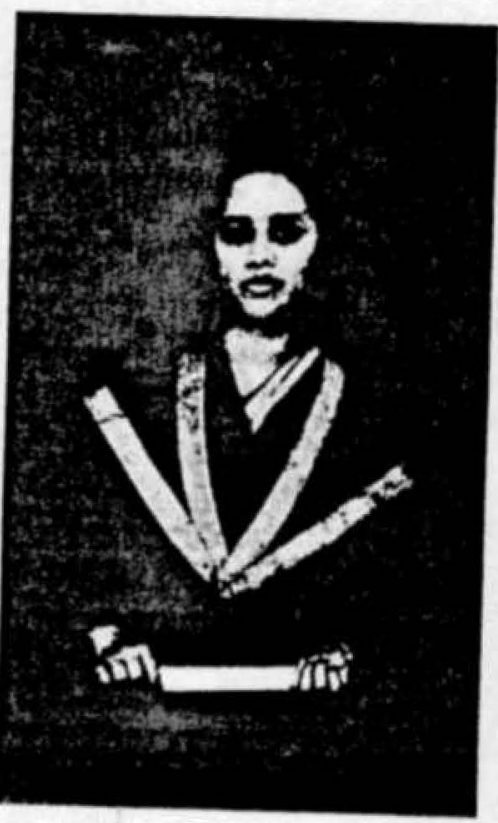

jure 6. Ma, with diploma (photo courtery the suthor).

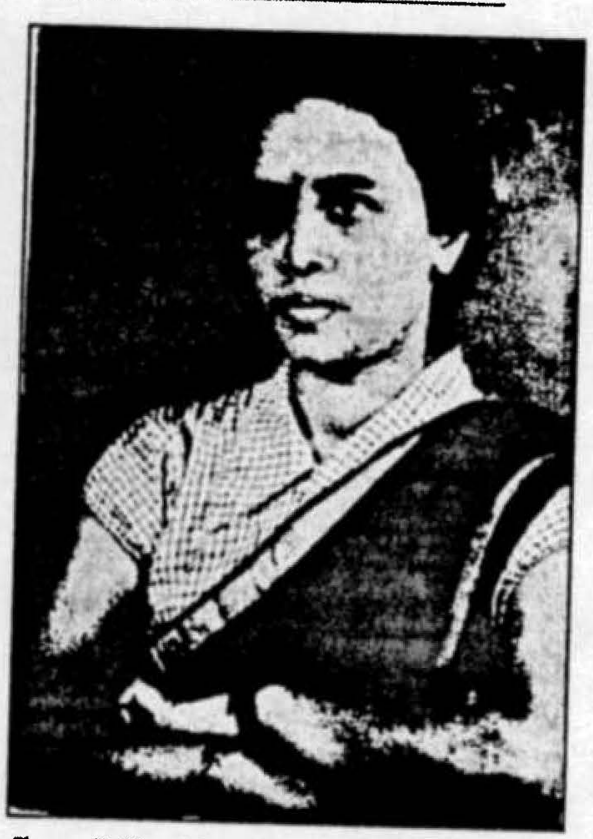
Figure 7. Ma, 5th August, 1941 (photo courtesy
of the outhor). in the other pictures. Perhaps this photograph marks the end of an arduous journey, both personal and academic, to award-winning professional, a doctor at last. Perhaps it was the photograph she attached to job applications.

A paternal aunt said, how your mother loved saris! But in college she didn't have the money to buy any. Baba would remember to me Ma's loud, openhearted laugh as she came down the stairs of the women's hostel at CMC ro meet him. She smoked, he said, until he got her to stop. She held hands with him under a dissected cadaver in anatomy class (said a classmate of theirs). This is how they first met, in his words, from his memoir:

The first year of medical college was of special significance to me. Here I met my classmate and friend who became my wife later. ... Fate brought us together." ..

We had just come oux of Practical Chemisry class. It was raining heavily. She had a big umbrella. I ran and rook shelter under her umbrella and stayed there forever. That was the beginning of our acquaintance which developed into friendship and college comradeship through our six years of college life, and ultimately after the end of the World War II culminated in our marriage.

Baba's next reference to my mother (always as "Miss Karmakar," later "Dr. Miss Karmakar," and eventually after 1943 as "my friend and fiance, Miss Karmakar") is a brief, but significant one, both in terms of her achievements as they graduated, as well as her personality. On the evening before their examination in surgery, he-an "ardent devotee" - walks to the temple of the goddess Kali near CMC. A severe storm breaks out. He waits, then after the storm abates, continues to the temple. After the exam, he learns from a friend that he has passed (he attributes the storm to his uncertainty, his success to his devotion to Kali). Another friend then informs him that $\mathrm{Ma}$ has ranked at the top in surgery, her success reported in the newspapers. She had written a note to him without mentioning this, for "she would never brag about this achievement!" Indeed, I never heard her talk about her achievements either. Baba refers again to Ma's "brilliant medical academic career" when he precedes her (and we follow) for graduate study at Guy's Hospital in London in 1954. She had thought of pursuing her studies too, he says, but decided against ir since my younger sister was about one year old, and $\mathrm{Ma}$ was "unhappy" about the creche where she would have to leave her. It is possible that this is his reading of her decision.

Ma would earn the Baccalaureate of Medicine and Bachelor of Science degree (MBBS) in 1941. Three medals, all dated 1941 and inscribed with her name, attest to her achievement, including a gold medal, the top award in her class for surgery, a silver medal for " $3 \mathrm{rd} \mathrm{MB}$ " (possibly as third overall ranking), and a silver medal with gold rim, inscribed with the name and insignia 
if "lord linlitheow. Viceros of lndia," but without further information." then I returned wo (.alcutes to conduce doctoral research in 1986, I discovred Mais medals in a dusty shoc box under my bed ar Baba's aparrment. I rought them back with me, in their square, satin-lined boxes, for safekeepng-precious matcrial mementos of her achievement, though I knew nothng of her stery then.

Ma recived her certification in Junc 1942, and then worked briefly at he ladv Dufferin (Imambara) Hospital in (hinsurah, Hooghly district, in re-Independence Bengal state. She moved, after being sexually harassed by he District Mawistrate, to the Lady Dufferin (Victoria) Hospital in Calcutta n 1943." She would tell me abour the terrible effects of the great Bengal amine of 194.3. where the bodies mostly of the rural poor lay on the streets if the cirs. Her farher had died in early 1945, as Baba, deployed with the MS co Europe, recurned home at the end of the War. Ma now took a poirion at the stare-rum Shambhunath Pandit Hospiral in Calcurta (SNPH) "hile Baba notes in his memoir that she applied to, and gor a position with, he prestigious Women' Medical Service, she decided to rake the state job it S.NPH. I can only assume that she made this choice with her family in nind, to be nearer to them. Ar SNPH she would describe to me the horrific niuries she treated in the Emergency Room, as Muslims and Hindus fell in each orher in the lead up to Independence and Partition into India and akistan. A few surviving letters, written by senior hospital officials, attest o Ma's excellent work in women's health, her management skills, her cometency in arnecological surgeries, blood transfusion, and anesthesia, her , leasant ways, and patients' high regard for her. Almost all attest to her good moral character." ()ne letter, written by a senior gynecologist apparently as Wa applice to the lady Dufferin hospital in Calcuta, given the date of the eference, notes

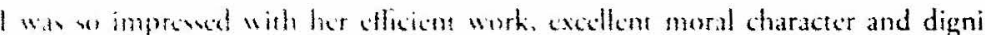
fied monners lhat 1 urongly recommended her contimation in her present post in

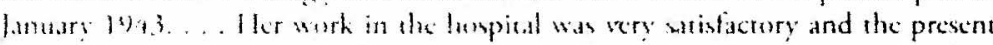

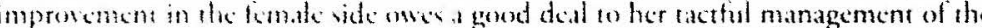

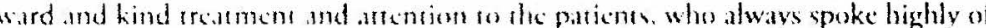
her. (2sth Fibruary 124,3 )

Ma married my tarher for lowe, and across caste difference, against some esistanci from my parernal grandmorher, who objected to her lower staus in that social hierarche." My parenes were married in Calcutra on 17th April, 1946, A $5 \times 7$ studio photograph of Ma nores on the back the date, and is eccipient, my farher: "11, Nowember 1946. To Bardhan" (Figure 8). I

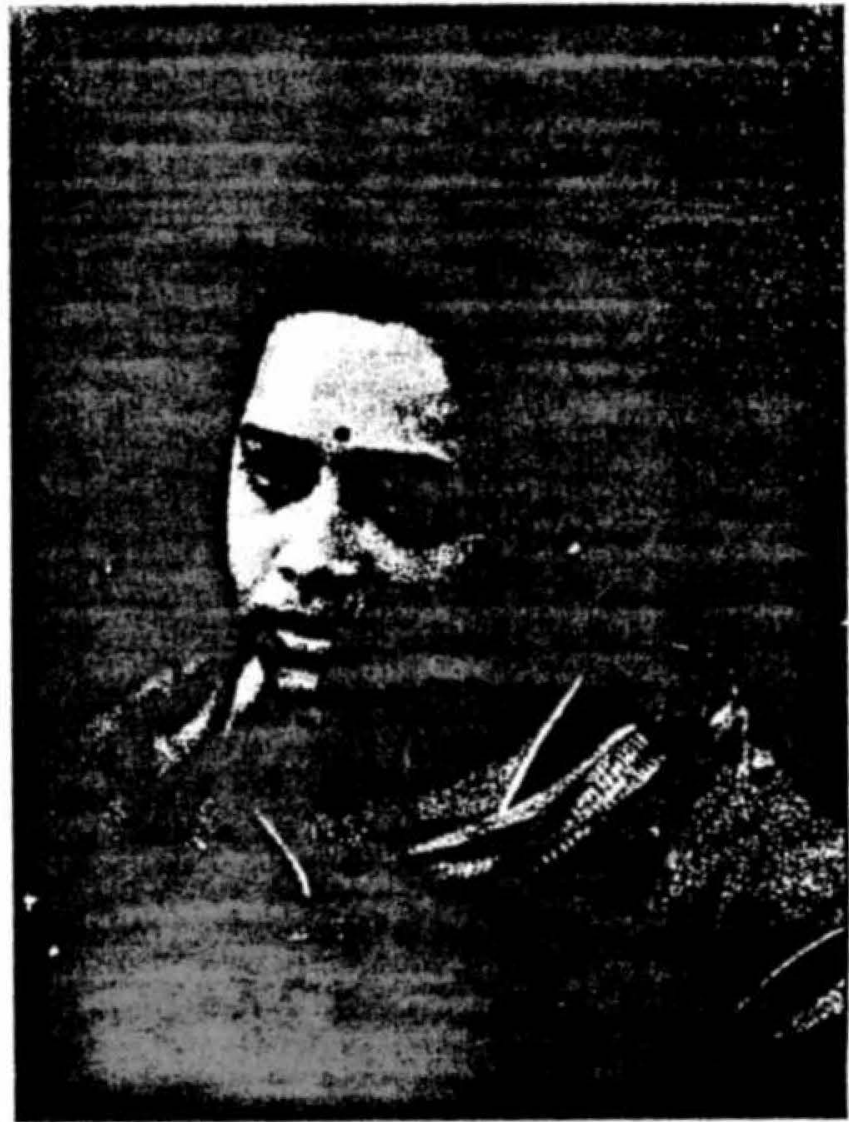

Figure 8. A new bride's gift to her husband, 11 th November 1946: "To Bardhan" (photo courtesy of the author).

especially notice in this photograph, evidently given to Baba seven months atter their wedding, a gentleness of expression different from the lively playful glamorous, or somber pictures above. She also does not wear a ghomta, or any jewelry, unusual in a newly married Indian woman. This is the only surviving studio photograph of $\mathrm{Ma}$ from the time that she was working.

Ma continued to work at SNPH until late into her pregnancy with me, at the end of 1948 , when she fell ill with high blood pressure. She joined my father, now the radiologist ar the army hospital in P'une, in western India. 
After my birth, Baba comments that his "family life started in full swing," and that it was a "happy" one. Baba would have a successful career in the Indian Army's Medical Corps. Ma, however, resigned from SNPH in September 1949, and did not pursue a career in medicine. She would work in an honorary and part-time capacity at the Family Planning Clinics of the Indian Red Cross Society in two Indian cities where my father was posted. Baba was transferred again to Pune in 1962, where Ma spent the last three years of her life.

Towards the end, I remember a mother who now moved slowly, after two strokes; who exercised her weakened fingers at the piano; who sat alone on the verandah, injecting herself with insulin; who very slowly negotiated the steep stone steps on a family visit to the ancient Buddhist caves of Ellora. I recall a quiet passivity, the flash of hurt on her face at a comment, without response, when she would have not let this go earlier. A paternal aunt and uncle tell me that her final stroke was precipitated by an ugly note from her brother, demanding money. On the morning of her final stroke I noticed her standing in front of the dresser mirror, pulling at her drooping mouth. That evening, as we stood at her bedside, and I chattered desperately at her, sensing something very wrong, her eyes sparked once with recognition, then faded, with finality. She died for me at that moment, a severance that has seared itself into my memory. Baba, at her bedside, looked silently at me, with an expression I read today as one that knew what lay ahead, for him, and for us. Over forty-seven days she would lie in a coma at the Pune military hospital, as Baba, my sister, and I watched her teeth and hair fall out, and her beaury fade. My sister and I would not be with her at her actual time of death, for Baba had sent us to the military club to be with other children. In the all-Commonwealth examinations in Class 11, I was to achieve top rank, with honors, in my class, and first division ranking. I would learn this while Ma lay in a coma-but she would nor. We left by train for Calcurta for her funeral, and Baba writes: "My wife, who was very fond of Calcurta and train journeys, traveled in an urn in her last journey to her beloved Calcurta."

After we returned from the funeral, Baba, in a rare expression of emotion in his memoir, describes the "all-pervading emptiness and loneliness ... [as if] the life of the house had been extinguished." I would soon leave for college, while he wrapped up the household and came to Calcurta with my sister, joining the military hospital as radiologist. "So, I left Pune," he writes, "where we first started our married life . . . and it is in Pune that our home shattered ... due to the untimely demise of a very nice, affectionate and loving wife and mother."

\section{CONCLUDING REFLECTIONS}

In the photographs above I have attempted to read the person that $\mathrm{Ma}$ appeared to want to present. In the interests of veracity and to the extent possible, I have substantiated my reading of those photographs with other "texts," including college reports, letters, testimonials, historical scholarship, my faincluding college reports, lotal accounts from family and friends. My own ther's meme cexts," this archival trove, but my voice has necmemories are a part of those "exts" this archival trove, definitive answers. Yet, essarily intervened, with many questions but without definitive answers. I can at the (inconclusive) end of this enterprise, I have a sense of discove

now both see some part of that story, even as I read who Ma was.

In contrast to my youthful memories of an unsentimental and academically demanding mother, the image $\mathrm{Ma}$ presents in her photographs (and in Baba's memoir and family anecdotes) reveals a young wom friends, and a boybeauty, evidently spirited, fun-loving, with many women fiends, and achievefriend. She appears self-possessed and confident, and proud ofial barriers of ment. She flirts, laughs heartily, loves, and marries across social barriers of caste and class. References from superiors at work testify I also learn of her filiked by her patients, a woman of moral rectitude. Yet I hather's death nancial struggles in CMC, and her need especially after her father's death to financially support her family. This possibly explains her decision to marry Baba soon after, for "security," as he would tell me. Her posed picture wire 2), her young children, an apparent image of compliant domesticity (Figure 2 ), contradicts the mother I remember. Yet there is some cohence, new bride, high-achieving medical student, the efficient docto

and the demanding, scolding, yet tender mother.

A fundamental question remains, one which I cannot read in photographs. Can I understand her early death in light of her immition? Family and ise, and her subsequent inability to see that promise to fruition? Family and friends note Ma's "frustration" at her inability to have a career in medicine, her tearful rages. My sister would tell me that she had often said that her $\mathrm{CMC}$ classmates, with lesser achievements, had gone on to haveral times, describes had not. This contradicts Baba's memoir, where he, several timuctive health her as "happy" - for example, in her volunteer work at re after they married, clinics. They had considered setting up in private practice after they in he would tell me, but the financial needs of the families at that point in time post-Partition, had made that a risky option.

I return to the image of the charred bone on my palm, for it is an image that has stayed with me, demanding explanation. While her final stroke is one that has say for her dere may be other possible narratives. Feminist 
analyses. drawing on psychoanalytical models from Lacan, note that mothers in Western iexts and culture are represented as more body than mind, "nature" rather than "culture," and withour voice in their privare, domesric sphere, and thite "culture," language, and the public sphere are associated with manculinity and the father (Bailcy and Cuomo; Boulous-Walker; Cahill; M. Hirsch, Morher/Latghtore; Sicgel). An Indian context offers less dichoromous perspecrives, where "nature" and "culture" are both cultural constructs, is Ramamujin has noud. In myth, for example, a powerful Hindu goddess embodying creative power (Sakti) defeats demons in batte, and is lauded as the "form" (rupu) of compassionate mother as well as wisdom and intelligence (Dein Mahatmyat 7: 19). In Indian philosophical thought, the concepts of mind and body are often likewise integrated. Linguistically cognates, the English "mind" and Bengali "mon" are respectively descended from sister languages L arin (mens), and Sanskrit (manas). While the functions of the "mind" are distinct from those of the body in the Cartesian tradition, in Indian contexts "mind"/ snon can simulrancously think, reflect, remember, hold secrets, fed cmorion, and be "broken"-like the (English) heart (mon bhenge jaowa).

been where indigenous tropes seem to empower women, however, it appears that historical and personal reality may be inversely related to metaphor. As Ma confroncd, at a critical juncture in Indian history, the social, cultural, and dass norms of her day (her "demons"), the specifics of her life's story do not fit tidily inw either a Lacanian, Western schema, or an indigenous (postcolonial) one. She aspired, achieved in a public sphere, "spoke" - and loudly (as I well remember) -even as a mother and wife, but was ultimately silenced. Where the mon is capable of "breaking," perhaps this silent and psychic injury in the face of mulciple patriarchies dealt her that final blow. In this context I share one more memory that has stayed with me, and which I try to unlerstand today. (On one cecasion (only), Ma, shortly preceding her death in Pune, sat at the dining table and remembered her father to my sister and me, ind quierly wiped the tears from her eyes. Perhaps he had, in her aspirations ind in her day, been her one support, her refuge. Her brothers, to the end, vould berrav her

Today 1 , her daughter and a feminist, seck to discover the systemic inquities she confronted and ranscended, but also those she could not. Reearching and writing this essuy and reflecting on its larger message for aspirng women has becn illuminaring for me, as it has been for a generation of counger women in my fimily. A niece would remark that she finally had a ontext for the photograph she had seen over the years (Figure 1). But it renains to be said that too many Indian women I know, including myself, in he diaspora and into the twenty-first cenrury, continue to negotiate, or fail while rying to negoriate, the uneasily bounded ypheres of public life and traditional constraints, confroming hose "demons" as our cost, "Ghar gha me fin cecry homel this in an issue," said a woman friend ro me, a physican and naturalized Indian Amcrican, in 2016.

\section{NOTES}

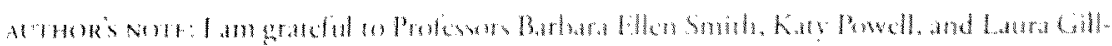

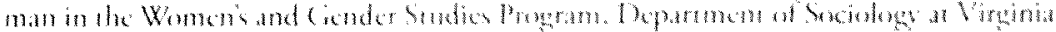

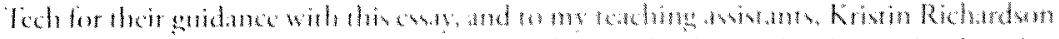

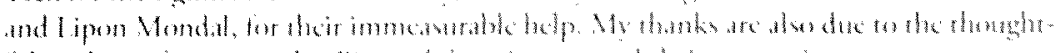

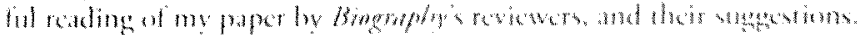

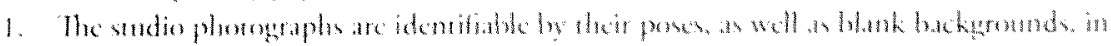

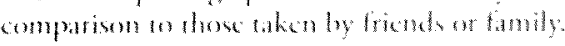

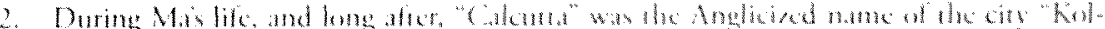

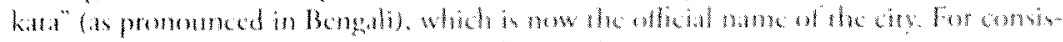

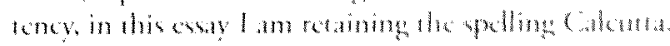

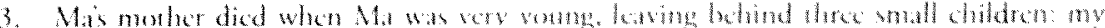

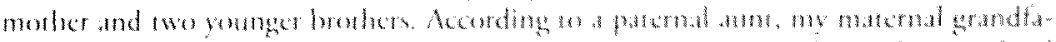

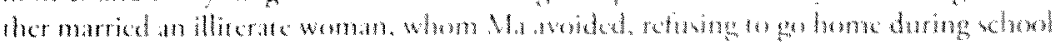
vacations.

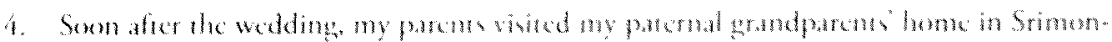

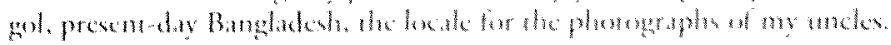

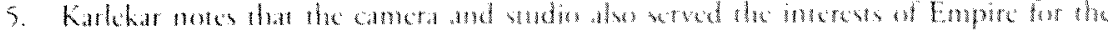

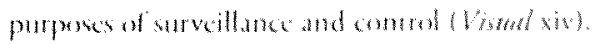

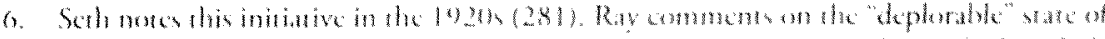

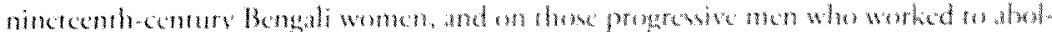

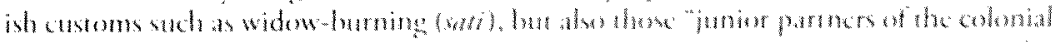

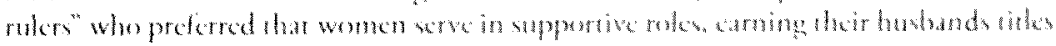
and honors from their colonid mastes $(179)$.

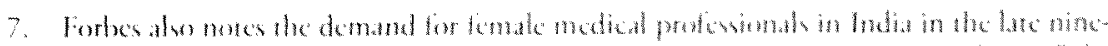

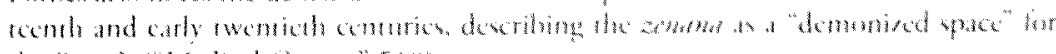
He British ("Medical Career" 518 )

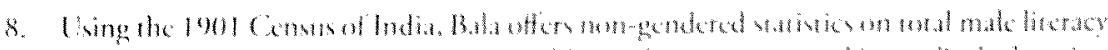

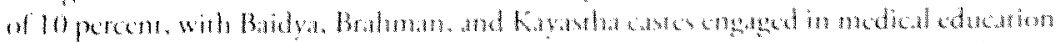

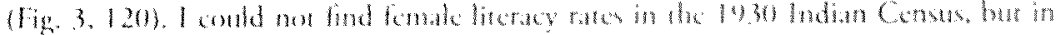
1950 hey were given as kes hon 10 percom.

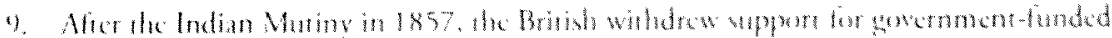

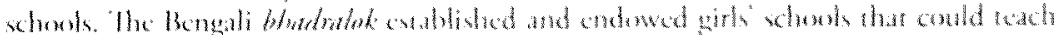

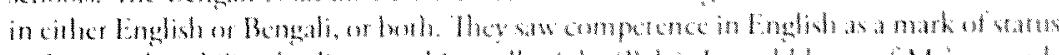

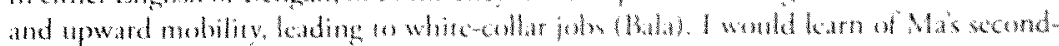

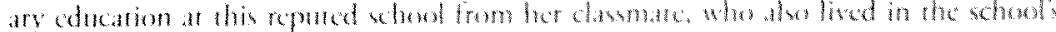
hosel with her 
10. Towards the end of the album, there is an uninscribed photograph of a lovely, darkeyed young woman who looks over her right shoulder at the camera, wirh her loose, black. long hair flowing behind her. This is the most overtly seductive picture of Ma's friends.

11. My father refers both to a political event as "fate," I think, as well as his first meeting with $\mathrm{Ma}$ in $\mathrm{CMC}$. The Chitragong Armory raid in 1930 by Indian freedom fighters, and the execution of its two leaders by the British in January 1934, resulted in the police "grabbing" him when he was about to interview at a medical school in Chittagong for a Licentiate degree (not the MBBS he would get from CMC). Earlier in his memoir he refers ro his pro-freedom activities, such as refusing when asked by his father's British superiors to spy on Indian revolutionaries. I can only infer that his arrest at the interview had to do with those actions, at a point when tensions were high in Bengal. The police clearance came too late for the application deadline. He applied to, and was accepted at, CMC. Ma too missed a deadline ar Campbell Medical College, and entered CMC the same year, 1935. Photographs of Baba appear some way into the album, of his travels with the IMS. On one page my parents appear together, but without provenance, possibly when $\mathrm{M}_{2}$ worked at Lady Dufferin Hospital in Chinsurah

12. The British Library in London, from where I got the Annual Reports, had none after the 1939-1940 year. As with the preceding years, the Reports list the award winners for the year. I have the medals, however, and both my parents' diplomas.

13. While Baba is vague about this incident in his memoir, a paternal unde identified the harasser.

14. This was a human-engineered famine that killed an estimated two million people in Bengal. It was caused by the shortage of rice, a staple that was being sent to the British and Indian rroops at war in Europe, and hoarding at home by indigenous black marketers.

15. British women doctors lobbied for the Women's Medical Service, which came into its own in 1914. Forbes nores that while the WMS, modeled on the all-male Indian Medical Service (which employed my father), professed concern for Indian women doctors, it was the British women who gained the most from it (Women 167).

16. Ma's last name, Karmakar, although also of the Kayastha caste, belongs to a lower category than that of my paternal family.

\section{WORKS CITED}

Annual Report on the Working of the Medical College. Calcurta. 1935-1936. British Library. Print.

Arnold, David. Colonizing the Body: State Medicine and Epidemic Disease in Nineteenth-Century India. Berkeley: U of California P, 1993. Print.

Bailey, Alison, and Chris Cuomo. The Feminist Philosophy Reader. New York: McGraw-Hill, 2008. Print.

Bala, Poonam. Imperialism and Medicine in Bengal A Socio-Historical Perspective. New Delhi: Sage, 1991. Print.
Barthes, Roland. Camera Lucida. New York: Hill and Wang, 1981. Print.

Boulous-Walker, Michelle. Philosophy and the Maternal Body: Reading Silence. London: Routledge, 1998. Print.

Bourdieu, Pierre. Photography. Stanford: Stanford UP, 1990. Print

Cahill, Susan. Mothers, Memories, Dreams and Reflections by Literary Daughters. Bargenfield, NJ: New American, 1988. Print.

Chatterjee, Partha. "The Nationalist Resolution of the Women's Question." Recasting Women. Essays in Colonial History. Ed. Kumkum Sangari and Sudesh Vaid. New Delhi: Kali for Women, 1997. 233-53. Print.

Devi Mahatmya. Trans. Swami Jagadiswarananda. Madras: Sri Ramakrishna Math, 1953 Print.

Forbes, Geraldine H. "Medical Careers and Healch Care for Indian Women: Parterns of Control." Women's History Revieu 3.4 (1994): 515-30. Web. 8 July 2016.

. "Small Acts of Rebellion: Women Tell Their Phorographs." Behind the Veil: Resis tance, Women, and the Everyday in Colonial South Asia. Ed. Anindita Ghosh. Ranikher. India: Permanent Black, 2007. 58-82. Print.

- Women in Modern India. 1996. The New Cambridge History of India Part 4, Vol. 2. Cambridge: Cambridge UP, 2007. Print.

Gorman, Mel. "Introduction of Western Science into Colonial India: Role of the Calcurta Medical College." Proceedings of the American Philosophical Society 132.3 (1988): 27698. Print.

Hirsch, Julia. Family Photographs: Content, Meaning, and Effect. New York: Oxford UP, 1981 Print.

Hirsch, Marianne. Family Frames: Photography Narrative, and Postmemory. Cambridge, MA Harvard UP, 1997. Print.

The Mother/Daughter Plot: Narrative, Pyychoanalysis, Feminism. Bloomington: Indiana UP, 1989. Print.

Karlekar, Malavika. Re-visioning the Past: Early Photography in Bengal 1875-1915. New Delhi: Oxford UP, 2005. Print.

. Visual Histories: Photograptry in the Popular Imagination. New Delhi: Oxford UP 2013. Print.

Lacan, Jacques. Ecrits: A Selection. Trans. Alan Sheridan. London: Tavistock, 1977. Print.

Pinney, Christopher. The Coming of Photography in India. London: The British Library, 2008. Print.

. "Coming Out Better." Where Three Dreams Cross: 150 Years of Photography from India, Pakistan and Bangladesh. Whitechapel Gallery, London, in collaborarion with Fotomuseum Winterthur. Winterthur, 2010. 25-33. Print.

Ramanujan, A. K. "Is There an Indian Way of Thinking?" Ed. McKim Marriort. India through Hindu Categories. New Delhi: Sage, 1990. 41-58. Print.

Ramaswamy, Sumathi. "The Work of Vision in the Age of European Empires." Empires of Vision: A Reader. Ed. Martin Jay and Sumathi Ramaswamy. Durham, NC: Duke UP, 2014. 1-22. 
Ray, Bharati. "The Freedom Movement and the Feminist Consciousness in Bengal, 19051929." From the Seams of History Essays on Indian Women. Ed. Bharati Ray. New Delh Oxford UP, 1995. 174-218. Print

Seth. Sanjay. "Nationalism, Moderniry, and the "Woman Question' in India and Chima." Journal of Asian Studies 72.2 (2013): 273 97. Print

- Siegel, Kristi. Women's Autobiographies, Culture, Feminism. American University Studies Series 27: Feminist Studies. New York: Peter Lang, 1999. Print.

\section{THE ENSLAVED NARRATIVE: WHITE OVERSEERS AND THE AMBIGUITY OF THE STORY-TOLD SELF IN EARLY AFRICAN-AMERICAN AUTOBIOGRAPHY}

\author{
SHEILA J. NAYAR
}

The self of autobiography comes into being in the act of writing, not before. -John Sekora, "Black Message/White Envelope" 509

\section{THE AUTOBIOGRAPHICAL ART OF COMPROMISE}

In the beginning of the eighteenth century, there was the Word, and the Word was vital, and the white man owned it. Glib and confrontational as the preceding may sound, it is also, in the American context, irrefutably true. But if ownership of the written word was denied most humans in bondage, that was because, in the context of the master-slave relationship, a literate slave was a dangerous slave. While the slave capable of reading could "trans" mit news that the master wanted to keep secret," such as news of slave uprisings, the writing slave could forge "free papers" and passes for fugitive slaves (Starling 244) - and of even greater peril, was "more apt to run away" (Hager 46). The presence of literate slaves thus "threatened to give lie to the entire system," as Heather Williams explains in broader sociological terms: "Reading indicated to the world that this so-called property had a mind, and writing foretold the ability to construct an alternative narrative abour bondage itself. Literacy among slaves would expose slavery, and masters knew it" (2).

No wonder, then, that many of the antebellum narratives tell of fellow slaves who resisted even glancing in a book's direction for fear of the punishments meted out to those caught interacting with the alphabet (Starling 244). In this sense, the slave was doubly enslaved: not only was she somebody else's material and economically tradable property, she was without the cultural, and arguably epistemic, capital essential to negotiating the civic and 